\title{
Effect of tolazoline in severe hyaline membrane disease
}

\author{
N. McINTOSH AND R. O. WALTERS \\ Department of Paediatrics, University College Hospital, London
}

SUMMARY Tolazoline hydrochloride was given as a pulmonary vasodilator to 20 preterm infants with severe hyaline membrane disease requiring mechanical ventilation who developed persistent severe hypoxaemia. The drug was only given when deterioration persisted despite changes in ventilation techniques and thus there were no control infants. A significant improvement in arterial oxygenation was observed, particularly in those infants without intracranial haemorrhage or pneumothorax. Nine of 10 infants who had an obvious clinical response to tolazoline survived, whereas only 2 survived out of 10 who failed to respond, both being subsequently shown to have pneumothoraces. There appears to be a place for the use of tolazoline in a severely hypoxaemic infant with hyaline membrane disease who is being ventilated and in whom arterial oxygenation cannot be improved by further increase in the inspired oxygen concentration or by alteration of ventilator settings, provided pneumothorax has been excluded.

The normal increase in pulmonary vascular resistance in response to hypoxaemia occurs in an exaggerated form in the newborn infant. Pulmonary artery pressure rises to systemic levels with the reappearance of a transitional pattern of circulation (James and Rowe, 1957; Rudolph and Yuan, 1966). In infants with severe hyaline membrane disease, this response increases the right-to-left shunting of blood leading to increasing hypoxaemia, which is unresponsive to either increases in the fractional inspired oxygen concentration $\left(\mathrm{F}_{\mathrm{I}} \mathrm{O}_{2}\right)$ or to alterations in mechanical ventilator settings (Chu et al., 1967; Stahlman et al., 1972; Gersony et al., 1976). Tolazoline hydrochloride has been suggested as a therapeutic agent for dilating the pulmonary arteries which might be used to improve arterial oxygenation (Cotton, 1965; Korones and Eyal, 1975; Goetzman et al., 1976). This report describes our experience with the use of tolazoline in 20 consecutively admitted infants with severe hypoxaemia due to hyaline membrane disease.

\section{Patients and methods}

Twenty critically ill preterm newborn infants with severe hyaline membrane disease born between October 1976 and July 1977, developed persistent severe hypoxaemia while being mechanically ventilated, and were given 48 doses of tolazoline. The clinical details of the infants are shown in Table 1.

St George's Hospital, London

N. MciNTosH, consultant paediatrician

Cambridge Military Hospital, Aldershot

R. O. WALTERS, consultant paediatrician
None of the infants had polycythaemia or hypoglycaemia, and all were managed by methods previously described (Blake et al., 1973). Six babies had coagulation abnormalities, 4 disseminated intravascular coagulation, and 2 had less specific abnormalities. Two infants had severe rhesus isoimmunisation requiring exchange transfusions.

The infants were all ventilated via an oroendotracheal tube with a constant flow pressure-controlled ventilator (Bourns BP 200). Mean peak airway pressure (PAP) was $29 \mathrm{~cm}$ (range 20-40) $\mathrm{H}_{2} \mathrm{O}$; mean end expiratory pressure (EEP) was $3.5 \mathrm{~cm}$ (range $0-5) \mathrm{H}_{2} \mathrm{O}$; median inspiration/expiration ratio $(\mathrm{I} / \mathrm{E}$ ratio) 1:1 (range 1:2-3:1); mean respiratory frequency (f) $30 / \mathrm{min}$ (range $25-40 / \mathrm{min}$ ).

Seventeen infants had umbilical artery catheters sited in the lower abdominal aorta. Fifteen of the catheters had oxygen electrodes at their tips (Searle), allowing the continuous monitoring of arterial oxygen tension $\left(\mathrm{PaO}_{2}\right)$ (Conway et al., 1976). In all infants, frequent blood-gas analyses were performed* on arterial samples obtained from either the arterial catheters or peripheral arteries.

The indication for giving the first dose of tolazoline was deteriorating hypoxaemia in the presence of an inspired oxygen concentration of $100 \%\left(\mathrm{~F}_{\mathrm{I}} \mathrm{O}_{2}=1 \cdot 0\right)$ and the failure to respond to various manipulations of ventilator settings intended to raise $\mathrm{PaO}_{2}$ (Blake et al., 1973; Herman and Reynolds, 1973). In 10 infants the $\mathrm{PaO}_{2}$ was less than $20 \mathrm{mmHg}$, in 6 it was between 20 and $30 \mathrm{mmHg}$, in 3 between 30 and 40 *IL 413 Blood-gas analyser calibrated with known gases. 
Table 1 Clinical details of 20 infants given tolazoline

\begin{tabular}{|c|c|c|c|c|c|c|}
\hline Group & Case & $\operatorname{Sex}$ & Birthweight $(g)$ & Gestation (weeks) & Diagnosis* & Outcome \\
\hline $\begin{array}{l}\mathbf{B} \\
\mathbf{A} \\
\mathbf{B} \\
\mathbf{A} \\
\mathbf{A} \\
\mathbf{B} \\
\mathbf{B} \\
\mathbf{B} \\
\mathbf{A} \\
\mathbf{A} \\
\mathbf{A} \\
\mathbf{B} \\
\mathbf{A} \\
\mathbf{A} \\
\mathbf{B} \\
\mathbf{A} \\
\mathbf{B} \\
\mathbf{A} \\
\mathbf{A} \\
\mathbf{B}\end{array}$ & $\begin{array}{r}1 \\
2 \\
3 \\
4 \\
5 \\
6 \\
7 \\
8 \\
9 \\
10 \\
11 \\
12 \\
13 \\
14 \\
15 \\
16 \\
17 \\
18 \\
19 \\
20\end{array}$ & $\begin{array}{l}\mathbf{M} \\
\mathbf{M} \\
\mathbf{M} \\
\mathbf{M} \\
\mathbf{F} \\
\mathbf{F} \\
\mathbf{M} \\
\mathbf{M} \\
\mathbf{F} \\
\mathbf{M} \\
\mathbf{M} \\
\mathbf{F} \\
\mathbf{F} \\
\mathbf{M} \\
\mathbf{F} \\
\mathbf{M} \\
\mathbf{F} \\
\mathbf{M} \\
\mathbf{F} \\
\mathbf{M}\end{array}$ & $\begin{array}{r}1360 \\
2013 \\
1333 \\
1825 \\
1080 \\
1930 \\
1798 \\
2430 \\
930 \\
2000 \\
1750 \\
700 \\
890 \\
2020 \\
2100 \\
1158 \\
1000 \\
750 \\
1300 \\
1045\end{array}$ & $\begin{array}{l}31 \\
33 \\
28 \\
31 \\
27 \\
37 \\
33 \\
33 \\
26 \\
33 \\
32 \\
26 \\
30 \\
35 \\
31 \\
32 \\
28 \\
31 \\
30 \\
30\end{array}$ & $\begin{array}{l}\text { HMD, PIE, PT, S } \\
\text { HMD, PT, C } \\
\text { HMD, PT, IVH } \\
\text { HMD, C, RF, PH } \\
\text { HMD } \\
\text { Rh, HMD, SAH } \\
\text { HMD, S, C, IVH } \\
\text { HMD, IVH, SAH } \\
\text { HMD, PT } \\
\text { HMD } \\
\text { HMD } \\
\text { HMD, PT, C, SAH, IVH } \\
\text { HMD } \\
\text { HMD } \\
\text { HMD, Rh, PT } \\
\text { HMD } \\
\text { HMD, PIE, C, PH, SAH } \\
\text { HMD, S } \\
\text { HMD } \\
\text { HMD, PT, C, SAH, IVH }\end{array}$ & $\begin{array}{l}\text { Survived } \\
\text { Survived } \\
\text { Died } \\
\text { Died } \\
\text { Survived } \\
\text { Died } \\
\text { Died } \\
\text { Died } \\
\text { Survived } \\
\text { Survived } \\
\text { Survived } \\
\text { Died } \\
\text { Survived } \\
\text { Survived } \\
\text { Survived } \\
\text { Survived } \\
\text { Died } \\
\text { Died } \\
\text { Survived } \\
\text { Died }\end{array}$ \\
\hline Mean & & & 1486 & $30 \cdot 8$ & & \\
\hline
\end{tabular}

*HMD = hyaline membrane disease, IVH = intraventricular haemorrhage, PIE = pulmonary interstitial emphysema, RF = renal failure, PT = pneumothorax, $\mathbf{R h}=$ severe rhesus isoimmunisation (see text), $\mathbf{S}=$ septicaemia, $\mathrm{C}=$ coagulopathy (see text),

$\mathbf{P H}=$ pulmonary haemorrhage, $\mathbf{S A H}=$ subarachnoid haemorrhage.

$\mathrm{mmHg}$, and in the remaining infant the $\mathrm{PaO}_{2}$ was $66 \mathrm{mmHg}$. Subsequent doses of tolazoline were given in 11 infants, who responded to the first dose, and in whom hypoxaemia recurred. Chest $x$-rays were taken before the use of tolazoline if time allowed, so as to exclude pneumothorax as a cause for the infant's deterioration. In 7 infants, pancuronium bromide in a dose sufficient to paralyse spontaneous respiration $(0.03-0.05 \mathrm{mg} / \mathrm{kg}$ repeated as necessary) was given without improvement before the administration of tolazoline.

The dose of tolazoline hydrochloride was 1-2 $\mathrm{mg} / \mathrm{kg}$ body weight given over 30 seconds, into a scalp vein (10 infants), into another vein ( 2 infants), or into the umbilical artery (8 infants).

Ventilator settings were recorded before and after each dose of tolazoline. In the 15 infants in whom the abdominal aortic $\mathrm{PaO}_{2}$ was recorded continuously, the records were analysed to determine the $\mathbf{P a O}_{2}$ one min before and the peak $\mathrm{PaO}_{2}$ within $10 \mathrm{~min}$ after the administration of tolazoline. In addition blood-gas analysis was performed before and after each dose of tolazoline.

Mean airway pressure (MAP) was calculated for each of the ventilator settings, using the formula

$$
\frac{(\text { PAP } \times \text { inspired ratio })+(\text { EEP } \times \text { expired ratio })}{\text { inspired }+ \text { expired ratio }}
$$

and changes in $\mathrm{PaO}_{2}$ were determined from the bloodgas and abdominal aortic oxygen electrode data. MAP has been shown to correlate well with alveolar arterial oxygen difference at slow respiratory rates (Herman and Reynolds, 1973), and so was used to measure changes in ventilation which might have contributed to changes in $\mathrm{PaO}_{2}$. Changes in $\mathrm{pH}$, $\mathrm{PaCO}_{2}$, and base excess (BE) were also noted.

Blood pressure was measured by ultrasound using a Doppler (1 infant) or by a transducer (Hewlett Packard) attached to the umbilical arterial catheter (12 infants).

Tolazoline administration is followed by peripheral vasodilatation (Grover et al., 1961), and this was apparent in our infants. In 13 of them infusion of either whole blood, normal saline, or $5 \%$ sodium bicarbonate was needed after the administration of tolazoline to maintain an adequate circulating blood volume and a normal blood pressure.

The data obtained relating to each dose of tolazoline were analysed, using Student's paired or unpaired $t$ test, as appropriate.

\section{Results}

Data obtained from continuously recorded abdominal aortic $\mathrm{PaO}_{2}$ are summarised in Table 2. An example of such a record showing the response to tolazoline from which these data were obtained is shown in the Figure. Data obtained from analysis of samples of arterial blood are summarised in Table 3.*

The 15 infants in which abdominal aortic $\mathrm{PaO}_{2}$ was continuously recorded received 41 doses of tolazoline (Table 2). There was a highly significant rise of $26 \mathrm{mmHg}$ in the abdominal aortic $\mathrm{PaO}_{2}$ after tolazoline injection $(\mathrm{P}<0.001)$, while $\mathrm{F}_{1} \mathrm{O}_{2}$ and MAP did not change significantly.

* Complete data may be obtained from the authors on request. 
Table 2 Summary of data obtained from abdominal aortic oxygen electrode

\begin{tabular}{|c|c|c|c|c|c|c|c|}
\hline \multirow[t]{2}{*}{ Group } & \multirow[t]{2}{*}{ Doses } & \multicolumn{3}{|c|}{ Before tolazoline } & \multicolumn{3}{|l|}{ After tolazoline } \\
\hline & & $\begin{array}{l}\text { Mean } M A P \\
\left(\mathrm{~cm} \mathrm{H}_{2} \mathrm{O}\right)\end{array}$ & Mean $F_{1} \mathrm{O}_{2}$ & $\begin{array}{l}\text { Mean } \mathrm{PaO}_{2} \\
(\mathrm{mmHg})\end{array}$ & $\begin{array}{l}\text { Mean } \triangle M A P \\
\left(\mathrm{~cm} \mathrm{H}_{2} \mathrm{O}\right)\end{array}$ & Mean $\Delta F_{1} \mathrm{O}_{2}$ & $\begin{array}{l}\text { Mean } \\
(\mathrm{mmHg})\end{array}$ \\
\hline \multicolumn{8}{|l|}{$\begin{array}{l}\text { Response to all doses of } \\
\text { tolazoline }\end{array}$} \\
\hline All patients $(n=15)$ & 41 & $17 \cdot 0$ & 1.0 & 28 & $-0.02(\mathrm{NS})$ & 0 & \multirow{3}{*}{$\begin{array}{l}+26 \\
(\mathrm{P}<0.001) \\
+38 \\
(\mathrm{P}<0.001) \\
+8 \\
(\mathrm{P}<0.05)\end{array}$} \\
\hline Group A $(n=9)$ & 24 & $16 \cdot 2$ & $1 \cdot 0$ & 34 & $\mathbf{0}$ & 0 & \\
\hline Group B $(n=6)$ & 17 & $18 \cdot 2$ & $1 \cdot 0$ & 21 & $-0.05(\mathrm{NS})$ & 0 & \\
\hline \multicolumn{8}{|c|}{$\begin{array}{l}\text { Response to 1st dose tolazoline } \\
\text { only }\end{array}$} \\
\hline All patients $(n=15)$ & 15 & $18 \cdot 6$ & $1 \cdot 0$ & 22 & $+0.2(\mathrm{NS})$ & 0 & \multirow{3}{*}{$\begin{array}{l}+39 \\
(\mathrm{P}<0.005) \\
+56 \\
(\mathrm{P}<0.005) \\
+14 \\
(\mathrm{P}<0.01)\end{array}$} \\
\hline Group A $(n=9)$ & 9 & $17 \cdot 4$ & 1.0 & 27 & $\mathbf{0}$ & $\mathbf{0}$ & \\
\hline Group B $(n=6)$ & 6 & $20 \cdot 3$ & 1.0 & 14 & $+0.4(\mathrm{NS})$ & 0 & \\
\hline
\end{tabular}

Group A: Infants without intracranial haemorrhage or pneumothorax; Group B: infants with either intracranial haemorrhage (4) or pneumothorax (2).

In the 9 infants who were not shown subsequently to have intracranial haemorrhage or pneumothorax (group A), the mean rise of $39 \mathrm{mmHg}$ in abdominal aortic $\mathrm{PaO}_{2}$ was significantly greater than in the 6 infants with either intracranial haemorrhage or pneumothorax (group B) in whom the mean rise in abdominal aortic $\mathrm{PaO}_{2}$ was $8 \mathrm{mmHg}(\mathrm{P}<0 \cdot 01)$. The response to tolazoline was more marked after the first dose, the mean rise in abdominal aortic $\mathrm{PaO}_{2}$ in all patients being $39 \mathrm{mmHg}$. In group $\mathrm{A}$ the mean rise of $56 \mathrm{mmHg}$ was significantly greater than in group $B$, in which the mean rise was 14 $\mathrm{mmHg}(\mathrm{P}<0.01)$.

Blood-gas data were obtained before and after 33 doses of tolazoline in 20 infants (Table 3). There was a significant rise of $21 \mathrm{mmHg}$ in $\mathrm{PaO}_{2}$ after tolazoline injection $(\mathrm{P}<0.01)$ which occurred despite a fall in $\mathrm{F}_{\mathrm{I}} \mathrm{O}_{2}$, while MAP did not change significantly. No significant change in $\mathrm{pH}, \mathrm{PaCO}_{2}$, or base excess occurred. In the 11 infants who were not shown subsequently to have intracranial haemorrhage or pneumothorax (group A), the mean rise in $\mathrm{PaO}_{2}$ was $26 \mathrm{mmHg}$ compared with the mean rise in $\mathrm{PaO}_{2}$ of $10 \mathrm{mmHg}$ in the 9 infants with intracranial haemorrhage or pneumothorax (group B). This difference is not statistically significant. If the 2 patients with pneumothorax are excluded from group $B$, the mean rise in $\mathrm{PaO}_{2}$ for the group is $4 \mathrm{mmHg}$ which is significantly different from the rise in group A $(P<0.05)$. When only the response to the first dose of tolazoline is considered, the mean rise in $\mathrm{PaO}_{2}$ after tolazoline was $33 \mathrm{mmHg}(\mathrm{P}<0.01)$ which occurred despite of a fall in $\mathrm{F}_{\mathrm{I}} \mathrm{O}_{2}$, while MAP did not change significantly. In group A the mean rise in $\mathrm{PaO}_{2}$ of $49 \mathrm{mmHg}$ was significantly greater than in group $B$ in which the mean rise was $14 \mathrm{mmHg}(\mathrm{P}<0.05)$.

\section{Discussion}

Tolazoline hydrochloride is chemically related to the sympathomimetic amines and histamine. It is a short-acting alpha adrenergic blocking agent, but in the doses used in the clinical situation this effect is negligible. It is also a histaminic agent and has a direct nonadrenergic relaxant action upon vascular smooth muscle, the vasodilator effect being greatest in regions where vasoconstriction is most pronounced (Grover et al., 1961). Tolazoline has been shown to relieve pulmonary vasoconstriction and in this respect it is believed to be most effective in those cases where pulmonary vascular resistance is increased due to a generalised constriction of hypertrophied small muscular arteries (Grover et al., 1961). This situation is similar to that seen in severe hyaline membrane disease with hypoxaemia, and pulmonary vasospasm has been demonstrated in such infants by Chu et al. (1967). The possible value of tolazoline in the management of severe hypoxaemia in infants with hyaline membrane disease has been suggested (Goetzman et al., 1976).

In our 20 deteriorating infants we demonstrated a significant rise in arterial $\mathrm{PaO}_{2}$ in response to tolazoline. The babies acted as their own controls as the drug was given only as a last resort when all other treatments had failed and it was felt that death was imminent. In infants who did not have intracranial haemorrhage or pneumothorax as a cause for their severe refractory hypoxaemia the improvement was more pronounced. The difference in response to tolazoline between the two groups was more marked with the first dose than with subsequent ones.

Of the 10 infants who had an obvious clinical 


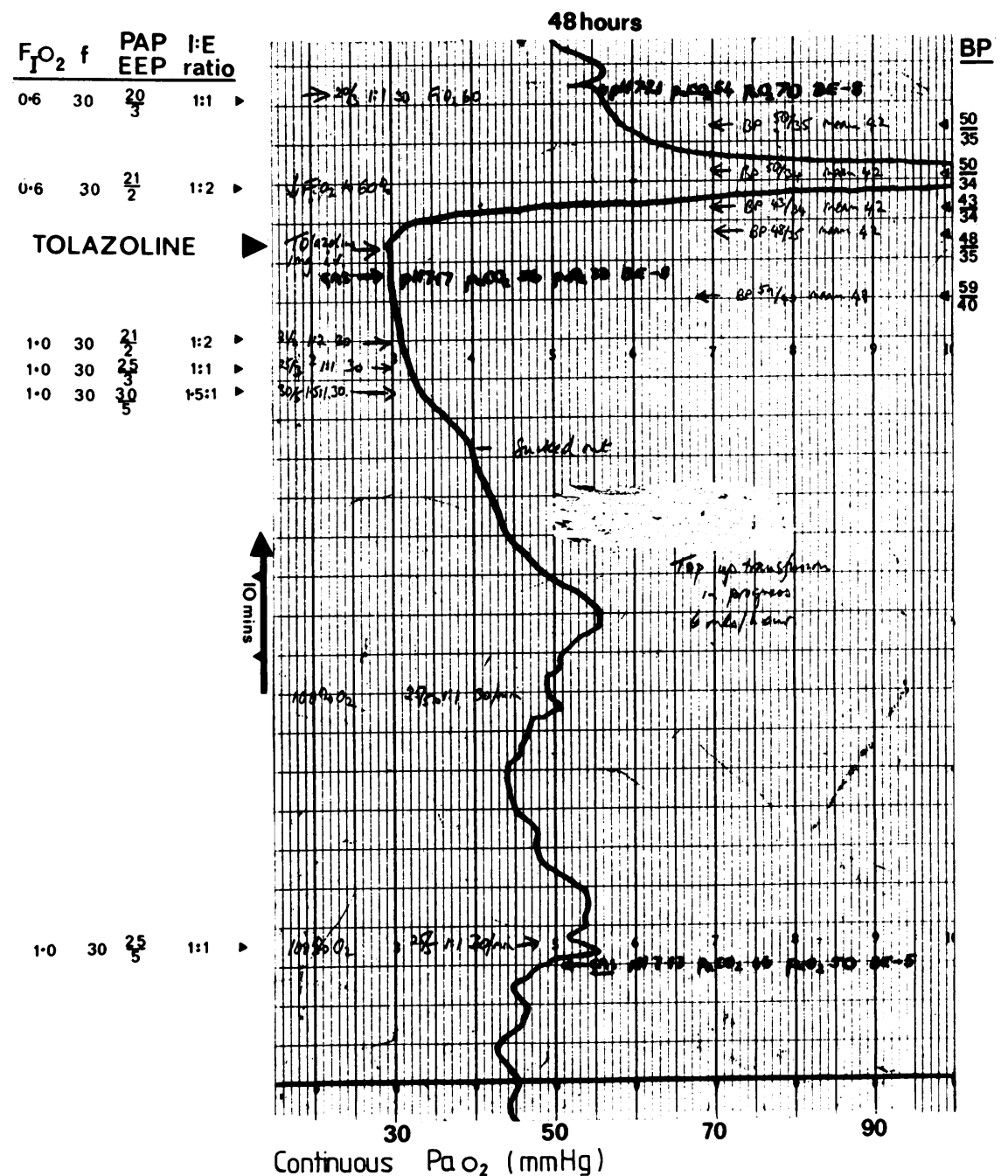

Figure Continuous $\mathrm{Pa}_{2}$ trace from baby in group $\mathrm{A}$ given intravenous tolazoline. Read trace from below up. Abbreviations as in text.

response to tolazoline, 9 survived, whereas only 2 out of 10 who failed to respond survived; both of these infants were subsequently shown to have pneumothoraces which were satisfactorily drained. These results suggest that the improvement in oxygenation resulting from the administration of tolazoline may lead to better survival in a group of infants who would otherwise have a high mortality. It is suggested that the mechanism for improvement is the breaking of the progressive vicious circle of increasing hypoxaemia, acidosis, and pulmonary vasoconstriction.

The known potential side effects of tolazoline are related to systemic hypotension and histaminic effects on the gastrointestinal tract. In our series systemic hypotension was not a significant problem because care was taken to maintain the circulating blood pressure. However, we consider that monitoring blood pressure is essential if this drug is used. Renal failure was observed in one patient, who died. This could be attributed in part to tolazoline, but the failure may have been due to hypoxic damage caused before the use of tolazoline. Extreme irritability accompanied by bloodstained cerebrospinal fluid observed in 2 patients, both of whom survived, might have resulted from leakage of red 


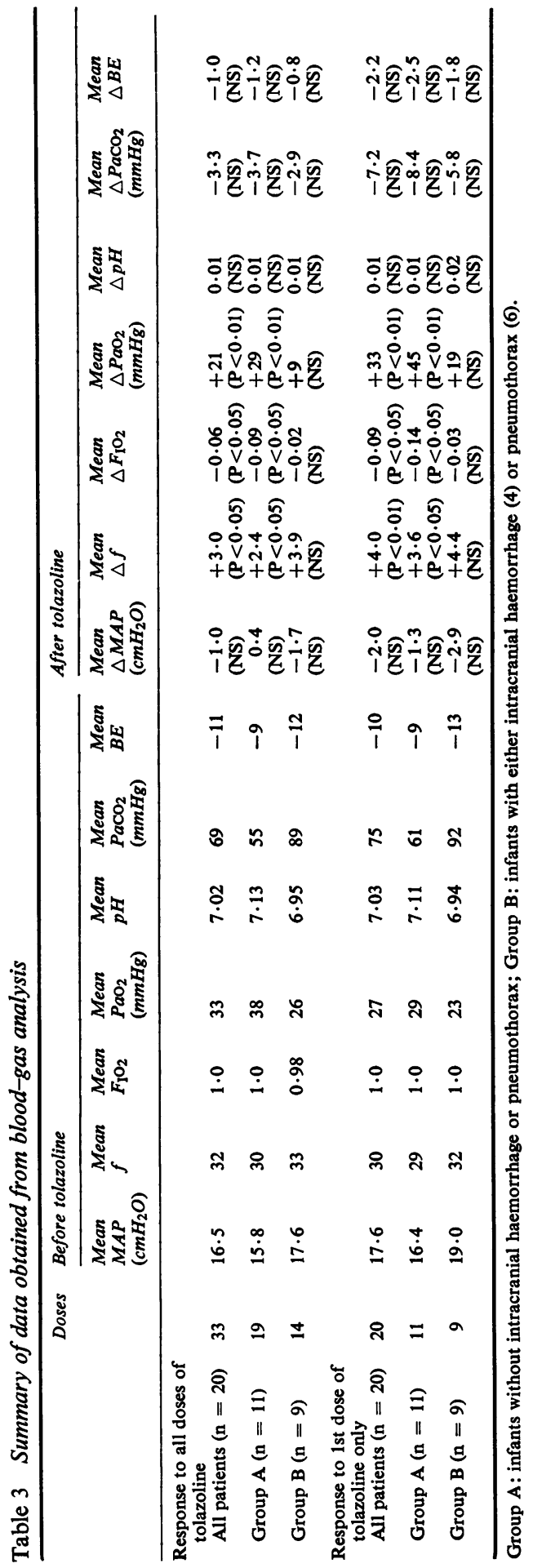


cells through a distended cerebral capillary bed to the cerebrospinal fluid. In neither case presenting in this manner was there apparent abnormality in the coagulation status which has been associated with subarachnoid haemorrhage (Chessells and Wigglesworth, 1971). Gastrointestinal problems were not encountered, although a potential hazard from reduced splanchnic flow might be necrotising enterocolitis; abdominal distension and haemorrhage have been well described by Goetzman et al. (1976).

We agree with Levin et al. (1976) that one definite indication for tolazoline is hypoxaemia with demonstrable difference between upper and lower body $\mathrm{PaO}_{2}$, implying persistence of transitional right-to-left circulation through the ductus arteriosus. This, in fact, occurred in only one baby in our series.

We conclude that there is a place for the use of tolazoline in a severely hypoxaemic infant with hyaline membrane disease who is being ventilated with an inspired oxygen concentration of $100 \%$ and in whom the $\mathrm{PaO}_{2}$ is unresponsive to alteration of ventilator settings. In these cases where chest movement is clinically normal and where pneumothorax has been radiologically excluded, tolazoline may have a dramatic effect.

We thank Professor E. O. R. Reynolds for encouragement throughout the study, and to medical and nursing staff on the Neonatal Unit at University College Hospital for co-operation.

\section{References}

Blake, A. M., Collins, L. M., Durbin, G. M., Hunter, N. J., MacNab, A. J., Reynolds, E. O. R., and Sellens, G. (1973). Simplified mechanical ventilation for hyaline membrane disease. Lancet, 2, 1176-1178.

Chessells, J. M., and Wigglesworth, J. S. (1971). Coagulation studies in severe birth asphyxia. Archives of Disease in Childhood, 46, 253-256.

Chu, J., Clements, J. A., Cotton, E. K., Klaus, M. H., Sweet, A. Y., and Tooley, W. H. (1967). Neonatal pul- monary ischaemia. I. Clinical and physiological studies. Pediatrics, 40, Supplement, 709-782.

Conway, M., Durbin, G. M., Ingram, D., McIntosh, N., Parker, D., Reynolds, E. O. R., and Soutter, L. P. (1976). Continuous monitoring of arterial oxygen tension using a catheter tip polarographic electrode in infants. Pediatrics, 57, 244-250.

Cotton, E. K. (1965). The use of priscoline in the treatment of the hypoperfusion syndrome. Pediatrics, 36, 149.

Gersony, W. M., Morishima, H. O., Daniel, S. S., Kohl, S., Cohen, H., Brown, W., and James, L. S. (1976). The hemodynamic effects of intrauterine hypoxia: an experimental model in newborn lambs. Journal of Pediatrics, 89, 631-635.

Goetzman, B. W., Sunshine, P., Johnson, J. D., Wennberg, R. P., Hackel, A., Merten, D. F., Bartoletti, A. L., and Silverman, N. H. (1976). Neonatal hypoxia and pulmonary vasospasm: response to tolazoline. Journal of Pediatrics, $89,617-621$.

Grover, R. F., Reeves, J. T., and Blount, S. G., Jr (1961). Tolazoline hydochloride (Priscoline). An effective pulmonary vasodilator. American Heart Journal, 61, 5-15.

Herman, S., and Reynolds, E. O. R. (1973). Methods for improving oxygenation in infants mechanically ventilated for severe hyaline membrane disease. Archives of Disease in Childhood, 48, 612-617.

James, L. S., and Rowe, R. D. (1957). The pattern of response of pulmonary and systemic arterial pressures in newborn and older infants to short periods of hypoxia. Journal of Pediatrics, 51, 5-11.

Korones, S. B., and Eyal, F. G. (1975). Successful treatment of persistent fetal circulation with tolazoline (abstract). Pediatric Research, 9, 367.

Levin, D. L., Heyman, M. A., Kitterman, J. A., Gregory, G. A., Phibbs, R. H., and Rudolph, A. M. (1976). Persistent pulmonary hypertension of the newborn infant. Journal of Pediatrics, 89, 626-630.

Rudolph, A. M., and Yuan, S. (1966). Response of the pulmonary vasculature of hypoxia and $\mathrm{H}^{+}$ion concentration changes. Journal of Clinical Investigation, 45, 399-411.

Stahlman, M., Blankenship, W. J., Shepard, F. M., Gray, J., Young, W. C., and Malan, A. F. (1972). Circulatory studies in clinical hyaline membrane disease. Biology of the Neonate, 20, 300-320.

Correspondence to Dr N. McIntosh, Department of Child Health, St George's Hospital, Blackshaw Road, London SW17 0QT.

Received 2 August 1978 